\title{
Econometric Analysis of Agricultural Intensification Techniques of Household Farmers in Nigeria
}

\author{
Osuji E. E. ${ }^{1, *}$, Onyeneke R. U. ${ }^{1}$, Balogun O. L. ${ }^{2}$, Tim-Ashama A. C. ${ }^{3}$, Onyemauwa C. S. ${ }^{4}$, Praise N. C. ${ }^{5}$, \\ Azuamairo G. C. ${ }^{1}$, Amadi M. U. ${ }^{1}$, Obi J. N. ${ }^{1}$, Ibekwe C. C. ${ }^{4}$, Obasi I. O. ${ }^{6}$, Njoku C. L. ${ }^{1}$, Izuogu C. U. ${ }^{1}$, \\ Ebe F. E. ${ }^{6}$, Ugochukwu G. C. ${ }^{7}$

\begin{abstract}
${ }^{1}$ Department of Agriculture, Alex-Ekwueme Federal University Ndufu Alike, Abakaliki, Nigeria ${ }^{2}$ Department of Agricultural Economics and Extension, Babcock University, Ilishan-Remo, Nigeria ${ }^{3}$ Department of Agricultural Science, Alvan Ikoku Federal College of Education, Owerri, Nigeria ${ }^{4}$ Department of Agricultural Economics, Federal University of Technology Owerri, Imo State, Nigeria ${ }^{5}$ Department of Cooperative Economics and Management, Institute of Management and Technology, Enugu, Nigeria

${ }^{6}$ Department of Agricultural Economics, Michael Okpara University of Agriculture, Abia State, Nigeria ${ }^{7}$ Department of Agricultural Technology, Federal Polytechnic Nekede, Owerri Imo State, Nigeria
\end{abstract}

Received July 26, 2021; Revised September 15, 2021; Accepted October 17, 2021

\section{Cite This Paper in the following Citation Styles}

(a): [1] Osuji E. E., Onyeneke R. U., Balogun O. L., Tim-Ashama A. C., Onyemauwa C. S., Praise N. C., Azuamairo G. C., Amadi M. U.1, Obi J. N., Ibekwe C. C., Obasi I. O., Njoku C. L., Izuogu C. U., Ebe F. E., Ugochukwu G. C. , "Econometric Analysis of Agricultural Intensification Techniques of Household Farmers in Nigeria," Universal Journal of Agricultural Research, Vol. 9, No. 6, pp. 289 - 299, 2021. DOI: 10.13189/ujar.2021.090607.

(b): Osuji E. E., Onyeneke R. U., Balogun O. L., Tim-Ashama A. C., Onyemauwa C. S., Praise N. C., Azuamairo G. C., Amadi M. U.1, Obi J. N., Ibekwe C. C., Obasi I. O., Njoku C. L., Izuogu C. U., Ebe F. E., Ugochukwu G. C. (2021). Econometric Analysis of Agricultural Intensification Techniques of Household Farmers in Nigeria. Universal Journal of Agricultural Research, 9(6), 289 - 299. DOI: 10.13189/ujar.2021.090607.

Copyright $\odot 2021$ by authors, all rights reserved. Authors agree that this article remains permanently open access under the terms of the Creative Commons Attribution License 4.0 International License

\begin{abstract}
Agriculture is the principal source of income for the majority of Nigerian rural households, but it has suffered significant setbacks in recent years, resulting in lower productivity and returns on investment. The study looked at the econometric analysis of household farmers' agricultural intensification strategies in Imo State, Nigeria. With the help of standardized questionnaires, 198 household farmers were selected using a multi-stage sample technique. The Beta regression model and descriptive statistics were used to analyze the data collected. Cassava, maize, and pumpkin leaves had the highest average outputs of $88.712 \mathrm{~kg}, 87.901 \mathrm{~kg}$, and $85.990 \mathrm{~kg}$, respectively, which dominated the entire production cycle. Planting materials, soil nutrients, and land improvement activities cost the most, at $\$ 81.637 .75$, $\$ 74,402.82$, and $\$ 71,906.80$, respectively. At $1 \%$ and 5\% levels, the coefficients of age, sex, education, net farm income, farm size, extension contacts, and farming experience were statistically significant and influenced the intensification of sustainable agricultural techniques (SAT) in the area. The study recommends farmers to embrace
\end{abstract}

effective and long-term agricultural technologies in order to boost farm production and output. Extension personnel should also meet with household farmers on a regular basis to communicate important information about new technologies.

Keywords Agriculture, Intensification, Improved Soil Techniques, Beta Regression Model

\section{Introduction}

Food will be produced for a global population of 9.1 billion people in 2050, according to [1]. To accomplish this, agricultural production systems need to be altered to maximize the productive capabilities of household farmers, who make up of around $80 \%$ of the agricultural workforce [2]. With today's population, however, it's critical to figure out which technology and strategies are best for reaching this goal. As a result, more attention has been paid to the 
intensification of sustainable agricultural techniques (SAT). Growing food without depleting land and water resources, restoring soil fertility, increasing the sensitivity of agricultural systems, and improving their potential to absorb carbon and mitigate climate change are all significant advantages of these technologies [3]. Agriculture intensification generates both commercial and public benefits, making it a theoretically crucial means of developing "win-win" solutions to hunger, food security, and environmental issues [4]. By applying large amounts of biomass to the soil, causing minimal soil damage, conserving soil and water, boosting soil activity and variety, and reinforcing agricultural residue cycle mechanisms, this helps to improve the soil fertility and structure [5]. As a result, higher yields and greater system resilience can be achieved due to improved plant nutrient quality, increased water retention capability, and improved soil structure, contributing to increased land productivity, food security, poverty reduction, and improved rural livelihoods [6]. Again, widespread adoption of sustainable agriculture techniques has the potential to bring significant public environmental benefits, including improved watershed function, habitat recovery, and carbon reduction. Agricultural intensification boosts output while reducing the requirement for further land conversion to agriculture, which emits almost as much GHG as agricultural operations [7]. Agriculture's technological mitigation capacity is expected to be between 4,500 and 6,000 $\mathrm{MtC} 02 / y e a r$ by 2030 [8], which can be achieved by reducing pollution, of which agriculture is a major source, accounting for $14 \%$ of global overall emissions, and increasing soil carbon sequestration, which accounts for 89 percent of agriculture's technical mitigation potential [9]. Agricultural intensification boosts output while reducing the requirement for further land conversion to agriculture, which emits almost as much GHG as agricultural operations itself [10]. SAT intensification and implementations increases small-holder farmers' income through farm revenues, ensuring higher food commodity prices, and reducing production risk at different levels [11]. Cover crops are reported to boost yields by minimizing deforestation and nitrogen leaching on the farm, as well as grain losses from insect assaults. Crop rotation and multiple cropping are aimed to ensure that nutrients are absorbed and used in varied ways. In south western Nigeria, crop rotation increased maize yields to $3,414 \mathrm{~kg} / \mathrm{ha}$ (a 71 percent increase) and bean yields to $258 \mathrm{~kg} / \mathrm{ha}$ [12]. These strategies are thought to improve soil fertility, minimize reliance on artificial fertilizers, and enrich nutrient delivery to succeeding crops, resulting in increased income and yields (158 percent increase in yields). Following fallow periods, increased agricultural yields have been seen [13]. However, the amount of yield increase with each succeeding fallow is unpredictably variable. Organic fertilizing (compost and animal manure) has been demonstrated to boost yields in some circumstances. Farmers that adopt zero/minimum tillage and crop residue management, especially in semi-arid and dry-humid agro-ecosystems, have greater options to boost soil water retention, and their crop yields are often higher [14].

Again, contouring and strip cropping are two water conservation techniques that can assist to reduce soil erosion while improving soil quality and yields at the same time [15]. In Southeastern Nigeria, literature shows that contour and strip farming enhanced upland crop yields by roughly 150 percent. Agro forestry, which refers to soil-use techniques in which woody perennials (alley and taunga farming) are purposefully integrated with agricultural crops in systems ranging from very simple and sparse to very complex and dense, helps to improve land productivity by providing a favourable microclimate and permanent cover as well as improved soil structure, organic carbon content, increased infiltration and enhanced fertility, reducing the need for chemical fertilizers which have adverse effects in the long run [16,17]. Certain farmers' weak exposures and dispositions, on the other hand, encourage them to react to shocks by using some copping techniques linked to soil erosion, reducing long-term environmental protection efforts and resulting in rapid land degradation and denudation, which has a negative impact on farm productivity and income [18]. However, despite multiple efforts to produce basic foods for Nigeria's growing population, the track record of achievement has proven futile over time. This is due to a variety of unsustainable soil management approaches that are linked to soil erosion, nutrient depletion, and a decrease in food output. Although most empirical studies have looked at the impact of land conservation techniques / practices on crop farmers' output, productivity, and income levels, none has looked at the intensification of sustainable agricultural techniques of household farmers in Imo State, Nigeria, thus, the need for the study. In addition, the study proposes an overhauling and systematic modification of the old and out-dated agricultural practices such as the use of hoes, cutlass, shovels, etc., which before now had rendered agriculture moribund by integrating and reinforcing new and emerging output yielding agro-technologies for increased food production and income of household farmers, also the use and application of scientifically improved and advanced methodology differs this study from other previous empirical studies.

\section{Materials and Methods}

This study took place in Imo State, Nigeria, which covers 5,530 square kilometers. The state is located between $4^{0} 45^{\mathrm{I}} \mathrm{N}$ and $7^{0} 15^{\mathrm{I}} \mathrm{N}$ latitudes and $6^{0} 50^{\mathrm{I}} \mathrm{E}$ and $7^{0}$ $25^{\mathrm{I}} \mathrm{E}$ longitudes. The state is made up of 27 LGAs, which are divided into three agricultural zones: Owerri, Orlu, and Okigwe. Imo State was chosen for this study because of its enormous arable agricultural lands and the dominance of agricultural activity. For this investigation, a multi-stage sampling technique was adopted. Multi-stage sampling technique was mostly preferred due to the sample study 
area coverage. The study was carried out in three (3) agricultural zones (Owerri, Orlu and Okigwe), in order to equally draw uniform samples from these zones, multi-stage sampling technique is most required. Also the sampling in these zones was done in batches and/ or stages, which necessitated the use of Multi-stage sampling technique.

In the first stage, two local government areas (LGAs) were purposively picked from each of the state's three agricultural zones (Owerri, Okigwe and Orlu). These LGAs were chosen based on their predominant and intensive agricultural activity, as well as their usage of SAT. Ngor-Okpala and Ohaji Egbema from Owerri zone, Nwangele and Isu from Orlu zone, and Isi-ala-Mbano and Obowo from the Okigwe zone, giving a total of six (6) local government areas. The second stage entailed a random sample selection of household farmers from the list of registered crop farmers using SAT in each of the selected LGAs from the various zones of the state, and in accordance with the zonal ADPs in each of the selected LGAs. There were 102, 109, and 99 crop farmers in the Owerri, Orlu, and Okigwe zones, respectively. As a result, the sample population was unequal, thus a representation sample was drawn from 80 percent of the total population in each zone. This resulted in 82 crop farmers in Owerri zone, 87 in Orlu zone, and 79 in Okigwe zone, for a total sample of 248 crop farmers throughout the six local government areas. However, only 198 farmers were deemed to be useful for data analysis in the study. Descriptive statistics and the Beta regression model were used to analyze the data. This study found sixteen (16) modified SATs that have been employed in developed and developing countries around the world (USA, Canada, Italy, India, Gambia, etc) Thus, the farmers were asked to specify the ones they had employed in their respective localities and zones to sustain agricultural production. An ith farmer receives a score of one for each of them that he has practiced. The likelihood of ith use of the SAT to the overall score of all the SAT is used to calculate the total score per respondent for the number of techniques utilized. As a result, it was calculated as follows:

$$
\begin{gathered}
\text { Prob.SAT Use level }=\frac{q}{r} \\
\text { where; } 0 \leq \text { SAT Use level } \leq 1
\end{gathered}
$$

Where;

$\mathrm{Q}=$ No. of SAT adopted by a farmer

$\mathrm{R}=$ No. of SAT available to all farmers in the study area which is sixteen (16)

It should be noted that this study is premised on the fact that farmers had been recording low farm outputs, productivity and income via the usage and application of mundane/crude farm implements which previous studies had documented. In addition, previous studies had also used wrong econometric tools such as ordinary least square multiple regression, logit model, probit model, tobit model, etc, all are econometric models which were wrongly applied in analyzing household farmers' adoption of improved agricultural practices/techniques. Thus, this study differs from the previous studies in highlighting the usage and application of scientifically verified high yielding agricultural techniques with proven reports documented in this study. Secondly, this study used verified appropriate econometric model (Beta regression) which differs from previous studies. Thirdly, this study examined the extent of the usage and application of these verified agricultural techniques which equally differed from previous studies.

Thus, the preceding eqn.1 result was statistically fitted to the beta regression technique, which is used to model observation or data containing probability distributions, percentages, rates, or proportions without any types of censoring and/or threshold score. As a result, the data collection comprises continuous measurements or distributions, which make the beta regression model more consistent and compatible $[19,20]$. The proposed model is based on the assumption that the response variable has a beta distribution. As a consequence, using the maximum likelihood of the beta regression model, the use-intensification levels of SAT of the household farmers in the area were isolated. A modification of the beta density parameterization in terms of the variate mean and a precision parameter underpins the beta regression model [21]. In its most general form, the probability beta density $\mathrm{y}-\mathrm{B}(\mathrm{p}, \mathrm{q})$ for the dependent variable $\mathrm{y}$ is defined as;

$$
\mathrm{F}(\mathrm{y} ; \mathrm{p}, \mathrm{q})=\frac{\Gamma(p+q)}{\Gamma(p) \Gamma(q)} y^{p-1}(1-y)^{\mathrm{q}-1}, \quad 0<\mathrm{y}<1
$$

Where;

$\mathrm{p}$ and $\mathrm{q}$ are unidentified parameters determining the shape of the distribution. $\mathrm{p}, \mathrm{q}>0, \mathrm{y}$ is the dependent variable and $\tau($.$) is the gamma function.$

Transposing the distribution of the two parameters of density ( $p, q)$ to that of the mean $\mu$ and precision $\omega$, by setting $\mu=\mathrm{p} /(\mathrm{p}+\mathrm{q})$ and $\omega=\mathrm{p}+\mathrm{q}$; we now have

$$
\begin{gathered}
\mathrm{F}(\mathrm{y} ; \mu, \oplus)= \\
=\frac{\Gamma \omega}{\Gamma(\mu, \omega) \Gamma(1-\mu) \oplus)} y^{\mu \oplus-1}(1-y)^{(1-\mu) \oplus-1}, \quad 0<\mathrm{y}<1
\end{gathered}
$$

Where

$0<\mu<1$ and $\omega>0$. From eqn. $3, \mathrm{E}(\mathrm{y})=\mu$ and $\operatorname{Var}(\mathrm{y})=$ $\mu(1-\mu) /(1+\omega)$ were defined as the mean and variance of the random variable $y$. The parameter $\omega$ is known as the precision since for fixed $\mu$, the larger the $\omega$, the smaller the variance of $\mathrm{y}$; while $\omega^{-1}$ is dispersion parameter.

Note; y's variance is a function of $\mu$, thus, the beta regression model based on parameterization is naturally heteroskedastic.

$$
\operatorname{Var}\left(\mathrm{y}_{\mathrm{i}}\right)=\frac{\mu i(1-\mu i)}{1+\omega}=\frac{g-^{1}\left(\mathrm{x}_{1}^{\frac{T}{1}} \beta\right)\left\{1-g-^{1}\left(\mathrm{X}_{1}^{T} \beta\right)\right\}}{1+\omega}
$$

Let; $\mathrm{y}_{1 \ldots \ldots \ldots . . . .} \mathrm{y}_{\mathrm{n}}$ be random samples such that $\mathrm{y}_{1-} \beta\left(\mu_{\mathrm{i}}, \oplus\right)$, $i=1 \ldots n$.

Thus, the beta regression model is defined as follows;

$$
\mathrm{g}\left(\mu_{\mathrm{i}}\right)=\mathrm{X}_{\mathrm{i}}^{\mathrm{T}} \beta+\mathrm{r}_{\mathrm{i}}=\dot{\eta}_{\mathrm{i}}
$$


Where,

$\beta=\left(\beta_{1} \ldots \ldots \ldots \beta_{\mathrm{k}}\right)^{\mathrm{T}}$ is a $\mathrm{k} \times 1$ vector of unknown regression parameters $(\mathrm{k}<\mathrm{n}), \mathrm{X}_{\mathrm{i}}=\left(\mathrm{x}_{\mathrm{i} 1 \ldots \ldots \ldots \ldots} \mathrm{X}_{\mathrm{ik}}\right)^{\mathrm{T}}$ is the vector of $\mathrm{k}$ regressors or independent variables or covariates and $\eta_{\mathrm{i}}$ is a linear predictor for the ith observation, i.e. $\left(\dot{\eta}_{\mathrm{i}}=\left\{\beta_{1} \mathrm{x}_{\mathrm{i} 1}+\beta_{\mathrm{k}}\right.\right.$ $\left.\mathrm{x}_{\mathrm{ik}}\right\}$, usually $\mathrm{x}_{\mathrm{i} 1}=1$; for all $\mathrm{i}$, accommodating intercept and $\mathrm{n}$ is the sample size. Here $\mathrm{g}():.(0,1)$ - IR is a link function, which connect the linear predictor and the response variable. Thus, the beta regression logit link function is expressed as;

$$
\mathrm{g}(\mu)=\log \mu /(1-\mu)
$$

The $\log$ likelihood of the beta regression model is estimated thus,

$$
\begin{array}{r}
\left.L_{\mathrm{i}}\left(\mu_{\mathrm{i},},\right)=\log \Gamma(\omega)-\log \Gamma\left(\mu_{\mathrm{i}} \oplus\right)-\log \Gamma\left(1-\mu_{\mathrm{i}}\right) \omega\right\}+\left(\mu_{\mathrm{i}} \oplus\right. \\
\left.-1) \log \mathrm{y}_{\mathrm{i}}+\left\{1-\mu_{\mathrm{i}}\right) \omega-1\right\} \log \left(1-\mathrm{y}_{\mathrm{i}}\right)
\end{array}
$$

Note that, $\mu_{\mathrm{i}}=\mathrm{g}^{-1} \mathrm{X}_{1}^{\frac{T}{1}} \beta$ is a function of $\beta$, the vector of regression parameters. In this study, the parameter estimation was done by the maximum likelihood (ML) of the beta regression model, thus the response and explanatory variables were explicitly specified as follows;

Prob.SAT; Use-intensification levels = Proportion of SAT used by the ith farmers'

$\mathrm{B}=$ Vector of unknown coefficients

$r_{i}=$ Error term, assumed to be independently distributed with mean zero and constant variance

$\mathrm{X}_{\mathrm{i}}=$ Vector of independent variables; which include;

$\mathrm{X}_{1}=$ Age of farmer (years)

$\mathrm{X}_{2}=$ Sex of farmer $($ male $=1$, female $=0)$

$\mathrm{X}_{3}=$ Education (No. of years spent in school)

$\mathrm{X}_{4}=$ Household size (No. of persons)

$\mathrm{X}_{5}=$ Net farm income (Naira)

$\mathrm{X}_{6}=$ Farm size (Hectare)

$\mathrm{X}_{7}=$ Returns from off-farm activities (Naira)

$\mathrm{X}_{8}=$ Distance of farm from farmer's homestead (kilometers)

$\mathrm{X}_{9}=$ Labour supply (Mandays)

$\mathrm{X}_{10}=$ Cost of land improvement practices (Naira)

$\mathrm{X}_{11}=$ Extension contacts (No. of visits)

$\mathrm{X}_{12}=$ Farming experience (No. of years spent on arable crop production)

\section{Results and Policy Implications}

\section{Socio-Economic Characteristics of the Household Farmers}

Table 1 showed that male farmers made up 51.5 percent of the total, while female farmers made up 48.5 percent. This means that Nigerian agriculture is still dominated by men, as men are the breadwinners, and this onus obligation forces them to care for their families at all times [22]. The farmers were on average 54 years old. This means that the majority of farmers is getting older and has accumulated enough practical knowledge to make reasonable judgments, enhance soil techniques, and increase productivity and resource use efficiency. The majority of the farmers (64.6 percent) were married with children, indicating a high level of family labor available in the farming industry. Their farming operations could be based on food production and family security [23]. Farmers with a secondary education made up of the majority, accounting for $57.6 \%$ of the total. This shows that education exposes farmers to new findings since the farmers in the area are able to read, write, and evaluate and use new production techniques [24]. The average household size was six people. This means that the size of the household was used to increase production efficiency [25]. The farmers' average farming experience of 15 years reflects their practical knowledge and in-depth experience in agricultural operations, which translates to improved crop performance and farm output [26]. The majority of farmers' farm holdings, $78.8 \%$, were less than one hectare. Small holdings may not be entirely cost-effective for implementing new technologies such as chemical weed control, farm mechanization, and so on, necessitating immediate attention to the provision of more arable agricultural lands for household farmers. The table also shows that during the cropping season, $86.9 \%$ of farmers had contact with extension agents, while 13.1 percent had no interaction with extension agents. This means that most household farmers were exposed to new and updated technologies with practical and technical uses on a regular basis [27]. 
Table 1. Socio-economic characteristics of the household farmers

\begin{tabular}{|c|c|c|c|}
\hline Socio-Economic Factors & Frequency & Percentage & Mean \\
\hline \multicolumn{4}{|l|}{ Sex } \\
\hline Male & 102 & 51.5 & \\
\hline Female & 96 & 48.5 & \\
\hline Age & & & 54 \\
\hline $21-30$ & 32 & 16.2 & \\
\hline $31-40$ & 43 & 21.7 & \\
\hline $41-50$ & 57 & 28.8 & \\
\hline $51-60$ & 66 & 33.3 & \\
\hline \multicolumn{4}{|l|}{ Marital Status } \\
\hline Single & 31 & 15.7 & \\
\hline Married & 128 & 64.6 & \\
\hline Separated/Divorced & 17 & 8.6 & \\
\hline Widow/Widower & 22 & 11.1 & \\
\hline \multicolumn{4}{|l|}{ Education } \\
\hline Primary & 67 & 33.8 & \\
\hline Secondary & 114 & 57.6 & \\
\hline Tertiary & 17 & 8.6 & \\
\hline Farming Experience & & & 15 \\
\hline $1-5$ & 19 & 9.6 & \\
\hline $6-10$ & 45 & 22.7 & \\
\hline $11-15$ & 61 & 30.8 & \\
\hline$>16$ & 73 & 36.9 & \\
\hline \multicolumn{4}{|l|}{ Other Occupation } \\
\hline Trading & 120 & 60.6 & \\
\hline Civil Servants & 36 & 18.2 & \\
\hline Tailoring & 16 & 8.1 & \\
\hline Artisans & 26 & 13.1 & \\
\hline Household Size & & & 6 \\
\hline $1-3$ & 29 & 14.6 & \\
\hline $4-6$ & 160 & 80.8 & \\
\hline $7-9$ & 38 & 19.2 & \\
\hline$>10$ & 26 & 13.1 & \\
\hline \multicolumn{4}{|l|}{ Farm Size } \\
\hline More than 1 ha & 22 & 11.1 & \\
\hline Less than 1 ha & 156 & 78.8 & \\
\hline 1ha & 20 & 10.1 & \\
\hline \multicolumn{4}{|l|}{ Extension Contacts } \\
\hline Contacts & 172 & 86.9 & \\
\hline No Contacts & 26 & 13.1 & \\
\hline Total & 198 & 100 & \\
\hline
\end{tabular}

Source: Field survey data (2019) 


\section{Descriptive Statistics of Different Outputs of Crops Produced}

Table 2 shows the descriptive statistics for the various crop outputs produced in the area. Amongst the tubers, the mean output for cassava and maize produced in the area were around $88.712 \mathrm{~kg}$ and $87.901 \mathrm{~kg}$. This means that cassava and maize production were very high in the area due to its complementary and conventional nature [28]. Other root and tuber crops grown in the area included yam, cocoyam, and potato, which produced $66.779 \mathrm{~kg}, 55.414 \mathrm{~kg}$, and $77.764 \mathrm{~kg}$ per cropping season, respectively, with over 255 farmers involved in its production [29]. This further emphasized the importance and domination of the crops in the area. Melon dominated all legumes cultivated in the area, with over $90 \%$ of farmers cultivating it and an average yield of $71.611 \mathrm{~kg}$ per cropping season. This emphasizes the grandness of legumes, which are a high-protein and edible-oil source. Furthermore, amongst the vegetables, pumpkin leaf and okra production dominated in the area, with mean outputs of $85.990 \mathrm{~kg}$ and $76.832 \mathrm{~kg}$, followed by cucumber, $65.980 \mathrm{~kg}$, pepper, $56.010 \mathrm{~kg}$, garden egg, $51.646 \mathrm{~kg}$, tomato, $46.901 \mathrm{~kg}$, etc [30]. However, plantain was another significant crop grown in the area, with over 100 percent of farmers producing it with a high average yield of $74.321 \mathrm{~kg}$. Others include bananas weighing 44.781 kilograms, pineapples weighing 64.843 kilograms, etc. It should be noted that some of these crops are seasonal in nature and hence, requires some forms of technical applications using SAT. It therefore follows that cassava, maize, and pumpkin leaves reported the highest mean production and productivity among the many crops produced in the area, owing to the significant concentration of the household farmers on these crops more than any other crops in the area.

Table 2. Descriptive statistics of different outputs of crops produced

\begin{tabular}{cccc}
\hline Crops & $\begin{array}{c}\text { *No of } \\
\text { Farmers }\end{array}$ & $\begin{array}{c}\text { Mean } \\
\text { Productivity }\end{array}$ & S.D \\
\hline Cassava & 198 & 88.712 & 30.09 \\
Yam & 102 & 66.779 & 21.94 \\
Pepper & 69 & 56.010 & 20.80 \\
Okra & 97 & 76.832 & 22.66 \\
Cocoyam & 67 & 55.414 & 23.86 \\
Plantain & 101 & 74.321 & 31.48 \\
Garden Egg & 89 & 51.646 & 28.60 \\
Maize & 198 & 87.901 & 29.92 \\
Melon & 96 & 71.611 & 23.40 \\
Tomato & 55 & 46.901 & 19.56 \\
Banana & 62 & 44.781 & 18.04 \\
Cowpea & 82 & 55.863 & 23.96 \\
Potato & 88 & 77.764 & 22.06 \\
Groundnut & 45 & 34.988 & 17.09 \\
Cucumber & 78 & 65.980 & 20.92 \\
Pineapple & 71 & 64.843 & 27.34 \\
Pumpkin leaf & 190 & 85.990 & 28.91 \\
Curry Leaf & 39 & 46.908 & 21.03 \\
Bitter Leaf & 36 & 47.943 & 22.92 \\
\hline
\end{tabular}

Source: Field survey data (2019).

*Multiple responses

\section{Descriptive Statistics of Different Inputs used in Crop Production}

Table 3. Descriptive statistics of different inputs used in crop production

\begin{tabular}{|c|c|c|c|c|}
\hline Variables & $\begin{array}{c}\text { No. of } \\
\text { Farmers }\end{array}$ & Unit & Mean & SD \\
\hline Farm size & 198 & $\mathrm{Ha}$ & 1.99 & 1.86087 \\
\hline Rent & 198 & N & $29,744.02$ & 2146.034 \\
\hline Labour & 198 & Man-day & 9 & 104.5824 \\
\hline Wage & 198 & N & $54,054.07$ & 2580.447 \\
\hline $\begin{array}{l}\text { Planting } \\
\text { materials }\end{array}$ & 198 & $\#$ & 81.637 .75 & 9959.304 \\
\hline $\begin{array}{l}\text { Cost of land } \\
\text { improvement } \\
\text { practices }\end{array}$ & 198 & 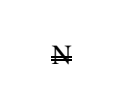 & $71,906.80$ & 8298.476 \\
\hline Soil nutrients & 198 & 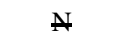 & $74,402.82$ & 9246.351 \\
\hline $\begin{array}{c}\text { Interest on } \\
\text { capital }\end{array}$ & 198 & 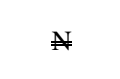 & $21,632.378$ & 255.6092 \\
\hline Depreciation & 198 & $\#$ & $3,374.26$ & 2173.103 \\
\hline
\end{tabular}

Source: Field survey data (2019)

Table 3 shows the descriptive data for the various inputs used in the farm production. The average area of cultivated land is $1.99+1.86087$ hectares. This indicates that the household farmers farmed on less than 2 hectares of farmland, implying a small-scale operation [31]. This could be owing to land fragmentation and skewed farm size holdings of household farmers caused by land shortages, making increased output and/or production extremely difficult. To increase agricultural productivity, a mean rent of $\$ 29,744.022146 .034$ was invested on lands. It should be noted that appropriate farmland holdings are required for increased production and adoption of new and improved techniques, and this stands as a significant barrier for most farmers, particularly those who do not have the financial means to rent farm property. Again, a mean labour size of $9 \pm 104.5824$ man-days and a mean wage of $\$ 54,054.07 \pm 2580.447$ per labour, per hectare of farmland was spent per farmer. Due to the high cost of hired labor in the area, this assertion implies that the quantity of labor allocated to agricultural production in the area is relatively minimal [32]. Planting materials cost an average of $\$ 81,637.75 .9959 .304$, while land improvement practices cost an average of $\$ 71,906.808298 .476$. In the same way, the average cost of soil fertilizers used by household farmers was $\$ 74,402.829246 .351$. This emphasizes the region's high cost of soil nutrients. As a result, the large standard deviation of the soil nutrient could be due to the widespread use of these fertilizers to improve soil fertility and increase agricultural productivity [33]. In addition, the cost of wear and tear of fixed inputs utilized in farm production was $\$ 3,374.262173 .103$, while the average interest rate on borrowed capital was $\$ 21$, 632.378255.6092. It can be seen that wear and tear, which is largely linked with fixed inputs, diminishes their useful life and salvage value, raising the expense of purchasing new ones. As a result, among the many agricultural inputs 
utilized in the area, planting materials, soil nutrients, and cost of land development procedures had the greatest mean cost and also had the widest standard deviations, indicating that these inputs were widely used and applied by the household farmers in the area.

\section{Determinants of Use-Intensification Levels of Sustainable Agricultural Techniques}

Table 4 shows the predicted factors of household farmers' use intensification levels of sustainable agricultural techniques (SAT). 81.2 percent of the model fitness is represented by the pseudo $\left(\mathrm{R}^{2}\right)$ value of 0.8119 . At $1 \%$ percent probability level, the log likelihood value of 187.02 was extremely significant. This means that the household farmers were able to maximize their yield by effectively utilizing the available better technologies. At $1 \%$ level of probability, the age coefficient was negative and highly significant, showing an inverse link between age and use intensification of sustainable agriculture technology (SAT). This suggests that elderly farmers are less willing and cautious to try out new and improved farm techniques [34], which could affect their use intensification levels. At 5\% level, the sex coefficient was negative and significant. This shows that female farmers are less ready to implement new technologies compared to the male farmers. Education coefficient was also significant and positive at $1 \%$, which implies that education improves the literacy of the farmer to adopt improved technologies [35]. Again, at 5\% probability level, the coefficient of net farm revenue was positive and significant. This means that as net farm revenue rises, so does the farmers use more of SAT [36].
The farm size coefficient was positively related to SAT use intensification levels and was statistically significant at the $1 \%$ level of probability. This means that any ith increases in the land holdings of household farmer's will trigger a complementary increase in SAT usage intensification [37]. That is, the larger a farm is, the more likely it is for a farmer to adopt a new technology. The cost of land improvement practices had a negative relationship with SAT and was significant at the 5\% probability level. This means that any increase in the cost of land improvement methods will result in a reduction in SAT usage. As a result, the high expense of land management procedures discourages farmers, particularly in rural regions, from adopting improved soil treatments. At the $1 \%$ probability level, the extension contacts' coefficient was positive and very significant. This means that a one-unit increase in extension contacts will result in a one-unit rise in SAT usage in the area. Extension interactions have been shown to increase farmers' inventive effectiveness, knowledge transfer, information distribution, and adoption drive. It is the agricultural vehicle for implementing improved soil management practices. The coefficient of farming experience was positively correlated to SAT use intensification and was significant at the $1 \%$ probability level. This means that when household farmers gain more agricultural experience, their level of use of SAT will rise in lockstep. Again, through interactions with other farmers and the outside world, experienced farmers are generally better and informed enough to access the importance of new technologies [37]. It should be noted that the significance of the regressor variables countered the null hypothesis tested.

Table 4. Maximum likelihood determinants of use-intensification levels of SAT

\begin{tabular}{|c|c|c|c|c|}
\hline Variables & Parameters & Coefficients & Z-values & Std Error \\
\hline Constant & $b_{o}$ & 0.09916 & $4.20901 * * *$ & 0.02355 \\
\hline Age of farmer & $\mathrm{b}_{1}$ & -0.70035 & $-3.30322 * * *$ & 0.21202 \\
\hline Sex of farmer & $b_{2}$ & -0.55031 & $-2.59013 * *$ & 0.21246 \\
\hline Education & $\mathrm{b}_{3}$ & 0.98109 & $4.55025 * * *$ & 0.21561 \\
\hline Household Size & $\mathrm{b}_{4}$ & -0.65619 & 1.00452 & 0.65323 \\
\hline Net farm income & $\mathrm{b}_{5}$ & 0.57024 & $3.88841 * * *$ & 0.14665 \\
\hline Farm size & $\mathrm{b}_{6}$ & 0.79414 & $4.60192 * * *$ & 0.17256 \\
\hline Return from off farm activities & $\mathrm{b}_{7}$ & 0.68987 & 1.09960 & 0.62738 \\
\hline Distance of farm from farmers homestead & $\mathrm{b}_{8}$ & 0.50343 & 1.05224 & 0.47843 \\
\hline Labour supply & $\mathrm{b}_{9}$ & 0.45231 & 1.45014 & 0.31190 \\
\hline Cost of land improvement practices & $b_{10}$ & -0.76613 & $-1.89011^{* *}$ & 0.40533 \\
\hline Extension contacts & $\mathrm{b}_{11}$ & 0.88240 & $4.55554 * * *$ & 0.19369 \\
\hline Farming experience & & 0.98731 & & \\
\hline Log likelihood & & $187.02 * * *$ & & \\
\hline Pseudo $\left(\mathrm{R}^{2}\right)$ & $b_{12}$ & 0.8119 & $3.74190 * * *$ & 0.26385 \\
\hline $\mathrm{N}$ & & 198 & & \\
\hline
\end{tabular}

Source: Field survey data, (2019)

Note: ***; ** indicates statistically significant at 1 percent, and 5 percent level of significance respectively. 
Table 5. Perceived agricultural intensification Deterrents

\begin{tabular}{|c|c|c|c|}
\hline Deterrents & $* *$ Frequency & Percentages & Rank \\
\hline Climate change & 99 & 50.0 & Low \\
\hline Capital & 198 & 100.0 & High \\
\hline Farm size & 108 & 54.5 & Low \\
\hline Environmental degradation & 98 & 49.5 & Low \\
\hline Fulani herd-men / cow attacks & 89 & 43.4 & Low \\
\hline Planting materials & 197 & 99.5 & High \\
\hline Pest / diseases outbreaks & 105 & 53.0 & Low \\
\hline Poor harvesting facilities & 76 & 38.4 & Low \\
\hline High labour cost & 120 & 60.6 & Low \\
\hline High Farm rent & 134 & 67.7 & High \\
\hline Poor storage facilities & 73 & 36.8 & Low \\
\hline Low yields & 145 & 73.2 & High \\
\hline High cost of soil nutrients & 195 & 98.5 & Low \\
\hline Land scarcity & 92 & 46.5 & Low \\
\hline $\begin{array}{c}\text { High cost of soil Improvement } \\
\text { Practices }\end{array}$ & 76 & 38.4 & Low \\
\hline Poor technical applications of SAT & 83 & 42.0 & Low \\
\hline Poor road networks & 133 & 67.2 & High \\
\hline Communication barriers & 86 & 43.4 & Low \\
\hline Transportation difficulties & 77 & 38.9 & Low \\
\hline High interest rate & 142 & 71.7 & High \\
\hline
\end{tabular}

Source: Field survey data, (2019)

***Multiple responses

\section{Conclusion and Recommendations}

Intensification of sustainable agricultural techniques generates both private and public benefits, and hence has the potential to produce "win-win" solutions to poverty, food security, and other environmental challenges. Male farmers accounted for 51.5 percent of the study's findings, while female farmers accounted for 48.5 percent. The average age of farmers was 54 years, indicating that the majority of the farmers were getting older and so had adequate experience to make sensible decisions, enhance soil techniques, and maximize productivity and resource use efficiency. Cassava, maize, and pumpkin leaves had the highest mean output among the numerous crops grown in the area, whereas planting materials, soil nutrients, and the cost of land development procedures were among the farm inputs with the highest standard deviation, reflecting a significant use of these inputs. At the $1 \%$ or $5 \%$ level, the coefficients of age, sex, education, net farm income, farm size, extension contacts, and farming experience were statistically significant and determined the area's intensification of sustainable agricultural approaches. Capital, coupled with climate change, farm size, farm inputs, and other factors, were seen as stumbling blocks to agricultural intensification in the area. To increase land productivity and production, the report advises farmers to embrace efficient and sustainable agricultural methods.
Extension specialists should also interact with the farmers on a regular basis to share critical information on better agricultural technologies.

\section{REFERENCES}

[1] Martin A., Coolsaet B., Corbera E., Dawson N., Fisher J., Franks P., Mertz O., PascualU., Rasmussen C. Ryan, "Land Use Intensification. The Promise of Sustainability and the Reality of Trade-Offs.” In (Eds.), Ecosystem Services and Poverty Alleviation, pp. 94-110, 2018.

[2] Struik P. C. T. W. Kuyper, "Sustainable Intensification in Agriculture: The Richer Shade of Green. A review." Agronomy for Sustainable Development, vol. 37, no. 5, pp. 39-45, 2017.

[3] FAO "Reports of Food, Agriculture and Organization", FAO, Rome, 2020.

[4] Smith A. "Measuring Sustainable Intensification in Smallholder Agro Ecosystems: A Review." Global Food Security, vol. 12, no. 4, pp. 127-138, 2017.

[5] Mabhaudhi T. "Mainstreaming Underutilized Indigenous and Traditional Crops into Food Systems: A South African Perspective". Sustainability, 11, pp. 172-176, 2019.

[6] Kenneth G. C., G. Patricio, "A global Perspective on Sustainable Intensification Research," Nature 
Sustainability, vol. 3, no. 2, pp. 262-268, 2020. www.nature.com/natsustainabilty/

[7] Pretty, J., "Global Assessment of Agricultural System Redesign for Sustainable Intensification". Nature and Sustainabilty, vol. 1, no. 2, pp. 441-446, 2018.

[8] Andrade, J. F., "A Spatial Framework for Ex-Ante Impact Assessment of Agricultural Technologies". Global Food Security, vol. 2, no. 20, pp. 72-81, 2019.

[9] FAO, "Improved Intensification methods", Reports of Food, Agriculture and Organization, FAO, Rome, 2021.

[10] Adeniran A. O., Akanbi O. M., O. B. Sidiq, "Strategy for Agricultural Intensification in Nigeria: Emphasis on Agricultural Aviation", International Educational Scientific Research Journal, vol. 1, no. 1, pp. 32-36, 2019.

[11] Mac-Ewan, O., Duncan, H., and Richard, A.A. "An Empirical Model of Crop Rotation". A Research Paper Submitted at the Australian Agricultural and Research Economics Society Conference Held at Melbourne Australia, pp. 8-11, 2011.

[12] Waikato, R.C. Sustainability Soil Management Practices in Developing Countries: A Theoritical Outlook. London. Cambridge University Press, pp. 34-29, 2009.

[13] Henri-Ukoha, A., Orebiyi, J. S., Uhuegbulam, I.J., Oshaji, I.O., and Ikenna, A., "Organic and Inorganic Manure Use among Vegetable Farmers in Owerri Municipal of Imo State, Nigeria. A Comparative Approach", Asian Journal of Agricultural Extension, Economics and Sociology, vol. 4, no. 2, pp. 166-170, 2015.

[14] Ehpriam, N., John, P., Crammer, K., Kato, E., and Samuel, M. "Policy options for increasing crop productivity and reducing soil nutrient depletion and poverty in Uganda". International Food Policy Research Institute. Environment and Production Technology Division. Discussion Paper, 134, 2015.

[15] Ekanem, E., Cynthia, A., and Augustine, A., "Determinants of poverty status of fish vendor households in lower Cross River Basin, Nigeria". Journal of Economics and Sustainable Development, vol. 6, no. 14, pp. 50-59, 2015.

[16] Issoufou Hassane Bil-Assanou, Daouda Boukari, Lawali Sitou Scaling up Assisted Natural Regeneration to Intensify Agroecologically Agrosystems Productivity. Universal Journal of Agricultural Research, vol. 8, no. 1, pp. 11-17, 2020. DOI: 10.13189/ujar.2020.080102.

[17] Dastan Bamwesigye, Azdren Doli, Kyom Jonathan Adamu, Sheku Kemoh Mansaray A Review of the Political Economy of Agriculture in Uganda: Women, Property Rights, and Other Challenges. Universal Journal of Agricultural Research, vol. 8, no. 1, pp. 1-10, 2020. DOI: 10.13189/ujar.2020.080101.

[18] Osuji E. E., Ehirim N. C., O. L. Balogun, "Impact of Sustainable Soil Management Techniques on Farm Output of Arable Crop Farmers in Imo State Nigeria.” International Journal of BioSciences, Agriculture and Technology, vol. 9, no. 3 , pp. 16-23, 2018.

[19] Osuji E. E., Okwara M. O., Anyanwu U. G., Effiong J.A.L., Praise C. N., D.C Irebuis "Economics of Farm Outputs of Arable Crop Farmers using Improved Soil Management Techniques in Imo State, Nigeria." International Journal of Agriculture and Earth Science, vol. 4, no. 3, pp. 1-7, 2018.
[20] Ferrari S., F. Cribari-Neto, "Beta Regression for Modeling Rates and Proportions". Journal of Applied Statistics, vol. 31, no. 12, pp. 799-815, 2004.

[21] Cepeda-Cuervo E. "Beta Regression Models; Joint and Mean Variance Modeling. Journal of Statistics and Theory Practic", vol. 9, no. 4, pp. 134-145, 2015.

[22] Paolino P. "Maximum Likelihood Estimation of Models with Beta-Distributed Dependent Variables." Political Analysis, vol. 9, no. 5, pp. 325-346, 2011.

[23] Mahon N., Crute I., Simmons E., M. M. Islam, "Sustainable Intensification OxymoronA Systematic Review", Ecological Indicators, vol. 74, no. 15. pp. 73-97, 2017.

[24] Lawry S., Samii C., Hall R., Leopold A., Hornby D., F. Mtero, "The Impact of Land Property Rights Interventions on Investment and Agricultural Productivity in Developing Countries, A Systematic Review". Journal of Development Effectiveness, vol. 9, no. 1, pp. 61-81, 2017.

[25] Osuji E.E. "Impacts of Sustainable Soil Management Techniques on Land Productivity and Poverty Status of Arable Crop Farmers in Imo State, Nigeria." PhD Dissertation, Michael Okpara University of Agriculture Umudike Nigeria, 2017.

[26] FAO, "Food, Agriculture and Organization, Climate Change and Food Security: A Framework Document" 107, FAO, Rome, 2018.

[27] FAO, "Food, Agriculture and Organization of the United Nations" (FAO), 2018b, https://doi.org/10.1007/s13593-01 7-0445-7

[28] Fawole F.B. "Chile's Agricultural Advisory Service for Small Farmers" 1978-2000". In Contracting for Agricultural Extension, (eds), International Case Studies \& Emerging Practices Wallingford, U.K. Press, pp. 134-142, 2018.

[29] Onyeneke R. U. "Determinants of Adoption of Improved Technologies in Rice Production in Imo State, Nigeria," African Journal of Agricultural Research, vol. 12, no. 11, pp. 888-896, 2017

[30] Shallo L., Ayele M., G. Sime, "Determinants of Biogas Technology Adoption in Southern Ethiopia." Energy Sustainable Society, vol. 10, no. 1. pp. 23-29, 2020, https://doi.org/10.1186/s13705-019-0236-x

[31] Qian G., Oreoluwa O., O. B. "Emmanuel Determinants of the adoption of sustainable intensification in southern African farming systems: A meta-analysis." Sustainability, vol. 12 , no. 6 , pp. 1-13, 2020.

[32] Victor O., Abegunde 1., Melusi S. 1., O. Ajuruchukwu, "Determinants of adoption of climate-smart agricultural practices by small-scale farming households in King Cetshwayo District Municipality, South Africa," Sustainability, vol. 12, no. 5, pp. 1-27, 2019.

[33] Okike I., Jabbor M. A., Manyong V., Smith J. W., Akinwumi J. A., S. K. Ehui, "Agricultural Intensification and Efficiency in the West African Savannah" Working paper, 33. International Livestock Research Institute (ILRI). Nairobi. Kenya, pp. 32-41, 2001.

[34] Birhanu Z., Traoré K., Sanogo K., Tabo R., Fischer G., A. M. Whitbread, "Contour Bunding Technology - Evidence 
and Experience in the Semi-Arid Region of Southern Mali," Renewable Agriculture and Food Systems, vol. 1, no. 2, pp. 33-44, 2020.

[35] Osuji E. E., Onyebinama I. C., Agu C. G., Eze E. U., C.C. Ibekwe, "Industrial Revolution of Africa's Agricultural Sector, A Paradigm Shift Transformation. International Journal of Agriculture \& Research, vol. 3, no. 5, pp. 01-10, 2020 .
[36] Chandra A., McNamara K.E., P. Dargusch, "Climate Smart Agriculture: Perspectives and Framings," Climate Policy, vol. 18 , no. 12, pp. 526-541, 2018.

[37] Etim N.A., G.E. Edet. "Estimating the Determinants of Poverty among Peri-Urban Telferia Occidentals Farmers in Uyo, Nigeria". Proceedings of 41 st Conference of the Agricultural Society of Nigeria, Samaru, October, 22-26th, pp. 434-436, 2007. 